\title{
Redes sociais: apresentação
}

Este número especial da $R A P$ aborda as redes sociais em suas diferentes perspectivas e aplicações, apresentando um panorama das vertentes de estudo sobre redes no contexto de práticas. Há muitas aproximações e contraposições.

Os artigos indicam o campo de aplicabilidade quanto aos temas e aos objetos de pesquisa. A análise de redes que vem polarizando as pesquisas empíricas na área organizacional sugere que as redes sociais influenciam o comportamento de indivíduos e grupos. Assim, os artigos discutem questões que passam por essa temática, pela análise de redes, abordando estrutura de governança, centralidade do poder e movimentos sociais.

Redes como perspectiva de análise e como estrutura de governança: uma análise das diferentes contribuições discute as abordagens de redes nas suas diferentes dimensões, mostrando como estas vêm se desenvolvendo, suas distinções e inter-relações. Segundo os autores, redes como estrutura de governança e como perspectiva de análise não devem ser tomadas como excludentes, mas sim como dimensões que precisam ser trabalhadas de forma integrada.

Redes em subsidiárias de multinacionais: um estudo de caso com análise de redes sociais de inventores e patentes apresenta uma visão da relevância estratégica de uma subsidiária de um grupo multinacional no setor de autopeças. Esse estudo de caso usa a análise de redes sociais e entrevistas com executivos para examinar uma rede de inventores e patentes depositadas entre 1978 e 2008 para o Grupo Sabó. O estudo analisa as competências essenciais desenvolvidas pela subsidiária bem como as métricas de rede, destacando o papel dos principais atores.

Governança e gestão social em redes empresariais: análise de três arranjos produtivos locais (APLS) de confecções no estado do Rio de Janeiro avalia as dificuldades encontradas em redes empresariais de três cidades do Rio de Janeiro - Cabo Frio, Petrópolis e Nova Friburgo - para a condução de uma governança sustentada na participação e na deliberação dos atores envolvidos nos APLs ali existentes. A teoria de redes empresariais, de APLs e de governança não espelha integralmente a realidade empírica, havendo dificuldades a serem superadas, não previstas nas discussões conceituais. A pesquisa identifica 
como se dão os processos de tomada de decisão e de gestão coletiva, reconhecendo problemas relativos à pouca capacidade de gestão dos empresários, à extrema heterogeneidade dos stakeholders e a um grau de confiança ainda incipiente entre os envolvidos, resultando em comportamentos ora predatórios, ora colaborativos por parte dos empresários.

Relações de poder em uma rede do terceiro setor: um estudo de caso analisa as relações de poder em uma estrutura de rede de organizações sem fins lucrativos: Cooperapic. Avalia a centralidade do poder no núcleo gestor da rede, o que pode ser um fator de manutenção da integridade estrutural. Nesse estudo de caso foram elaborados cenários de relacionamento entre os atores e mensurada a concentração de poder na rede, mostrando que a rede se constitui de forma descentralizada, com baixa centralidade e com subgrupos que concentram o poder, favorecendo sua fragmentação. Foi verificada ainda a importância do núcleo gestor na coesão da rede, bem como os impactos que poderiam ser ocasionados por sua exclusão.

Redes sociais em comunidades de baixa renda: os efeitos diferenciais dos laços fracos e dos laços fortes demonstra que os sistemas fechados de interação - capital social - e os abertos - laços fracos - são fenômenos de natureza distinta, que desempenham funções também distintas na determinação da capacidade de articulação coletiva de indivíduos e no grau de eficácia de ações coletivas. A abordagem principal do artigo é a de que enquanto o capital social tem a ver com maior capacidade dos membros da comunidade para articular mobilização social, os laços fracos têm a ver com a capacidade da comunidade em conseguir benefícios como saneamento básico, segurança pública, transporte coletivo, saúde e lazer. O estudo foi realizado em comunidades periféricas da Região Metropolitana de Belo Horizonte.

Abordagem de redes no estudo de movimentos sociais: entre o modelo e a metáfora parte de reflexões sobre as consequências do uso de abordagens fortemente influenciadas pela lógica empresarial como lentes para compreender movimentos orientados pela oposição a essa lógica. A partir de uma apropriação crítica de autores e formulações representativas dessa abordagem, incluindo a hibridização entre a(s) teoria(s) do capital social e o estudo de redes sociais e problematizando a classificação de Pierre Bourdieu como um teórico do capital social e da análise de redes. Na sequência é revisada a expressão predominante da abordagem de redes nos estudos sobre movimentos sociais, e logo depois a distinção entre metáfora e modelo. A autora afirma que a retomada da estratégia discursiva da metáfora poderia abrir espaço para reconhecer o novo, o que está em construção. Além disso, possibilitaria a coerência com a razão de ser do objeto a ser estudado. Assim, são apresentadas três 
metáforas - fluidos, teias e rizomas — de modo a ilustrar as potencialidades contidas no uso desse recurso no estudo de movimentos sociais.

Competências críticas ao desenvolvimento de mapas cognitivos de redes interorganizacionais identifica alguns dos conhecimentos e habilidades requeridos para a compreensão e abstração de redes interorganizacionais por intermédio de diagramas de rede. Para tanto, foi realizado um exercício prático junto a 102 alunos de administração, que deveriam desenvolver um diagrama de rede a partir da transcrição de falas de atores centrais de uma rede do cultivo de uva. Na fase de pré-análise das respostas os pesquisadores identificaram aspectos críticos para abstração de redes interorganizacionais, reflexão que auxiliou a definir os códigos requeridos para exploração do material por meio de análise de conteúdo: abstração de organizações com mesma função na rede; abstração de macroprocessos que compõem a rede; e abstração do ator central da rede. Além de apurar a grande dificuldade dos alunos para compreensão e abstração de redes interorganizacionais, a pesquisa auxiliou na identificação de algumas competências críticas para tal.

Luciano A. Prates Junqueira

Maria Ceci Misoczky 